\title{
PENGEMBANGAN ALAT UKUR KECEMASAN OLAHRAGA
}

\author{
Nyak Amir \\ FKIP Universitas Syah Kuala Banda Aceh \\ info@,infoaxe.net
}

\begin{abstract}
Abstrak
Tujuan penelitian ini adalah mengembangkan alat ukur yang memiliki validitas dan reliabilitas yang baik dan dapat diterapkan sesuai kondisi di Indonesia. Subjek penelitian $(\mathrm{N}=406)$ adalah seluruh atlet sepakbola pemula Kota BandaAceh. Metode pengembangan alat ukur ini dilakukan dengan dua kegiatan, yaitu: adaptasi instrumen, dan pengumpulan butir baru melalui item pool dan screening of item pool (Q-sort). Selanjutnya alat ukur ini diujicobakan melalui dua tahap, yakni uji coba tahap pertama dilakukan pada 406 atlet klub sepakbola pemula, dan uji coba tahap kedua dilakukan pada 1000 atlet klub sepakbola Provinsi Aceh. Data dianalisis melalui pembuktian validitas dan estimasi reliabilitas. Hasil penelitian menunjukkan bahwa validitas berada pada kategori baik, dan reliabilitas skala kecemasan pada kategori cukup, dan skala kecemasan olahraga yang terdiri atas 4 faktor dan 35 butir pernyataan ini dapat dipakai untuk mengukur kecemasan olahraga.
\end{abstract}

Kata kunci: pengembangan, alat ukur, kecemasan olahraga 
Jurnal Penelitian dan Evaluasi Pendidikan

\title{
SPORTS DEVELOPMENT TOOLS MEASURING ANXIETY
}

\author{
Nyak Amir \\ FKIP Universitas Syah Kuala Banda Aceh \\ info@,infoaxe.net
}

\begin{abstract}
The aim of this research is to develop standardized instrument with a good validity and reliability to measure sport anxiety which is suitable to local conditions in Indonesia. Subjects of the research were $(\mathrm{N}=406)$ beginner soccer players from Banda Aceh Municipality. The development of this measurement tool was conducted through two activities, namely instrument adaptation, and collection of new items through item pooling and screening of the item pool (Q-sort). Then the instrument was validated throught two phases, firstly on 406 beginner soccer players, and secondly, on 1000 soccer players from Aceh Province. Data were analysed through validity and reliability testing and factor analysis. Results show either the validity or the reliability level of anxiety scale was high enough, and that the sport anxiety scale comprising four factors and 35 items could be used to measure sport anxiety.
\end{abstract}

Keywords: development, measurement tool, sport anxiety

326 - Jurnal Penelitian dan Evaluasi Pendidikan Tahun 16, Nomor 1, 2012 


\section{Pendahuluan}

Permasalahan mendasar yang dihadapi oleh dunia persepakbolaan di Indonesia dan juga klub sepakbola pemula di Provinsi Aceh adalah hingga dewasa ini belum ada penerapan program pembinaan mental secara khusus dalam sistem pembinaan prestasi olahraga. Selain program pembinaan mental, belum juga ditemui adanya alat ukur baku yang dapat digunakan untuk mengukur tingkat kecemasan olahraga para atlet. Simpulan tersebut diperoleh melalui hasil pengamatan pada beberapa klub sepakbola pemula, serta didukung oleh hasil wawancara langsung dengan 18 atlet dan 6 pelatih klub sepakbola pemula di Kota Banda Aceh. Tidak adanya program pembinaan mental dan instrumen pengukuran kecemasan baku menyebabkan tidak terdeteksinya tingkat gangguan kecemasan para atlet, sekalipun beberapa atlet mengaku telah beberapa kali mengalami kecemasan saat menghadapi pertandingan.

Sampai saat ini tampaknya belum ada alat ukur kecemasan olahraga yang baku dengan tingkat validitas dan reliabilitas tinggi, yang dapat diterapkan di Indonesia sebagai alat untuk mengukur tingkat kecemasan olahraga. Sementara ini, khususnya di negara Barat telah terdapat sekurangkurangnya sepuluh instrumen kecemasan yang dapat digunakan sebagai alat mengukur kecemasan olahraga secara valid dan reliabel. Sayangnya, kesepuluh instrumen tersebut dikembangkan dalam konteks yang berbeda dengan latar belakang budaya Indonesia. Dalam kondisi seperti itu, instrumen tersebut tidak serta merta dapat dipergunakan untuk para atlet olahraga Indonesia. Oleh karena itu, diperlukan upaya-upaya mengadaptasi, memodifikasi, dan mengembangkan instrumen kecemasan olahraga yang dapat dipergunakan secara valid dan reliabel agar dapat diterapkan sesuai kondisi Indonesia. Terkait dengan hal tersebut, penelitian ini bertujuan mengembangkan alat ukur yang memiliki validitas dan reliabilitas yang baik dan dapat diterapkan sesuai kondisi di Indonesia

\section{Kecemasan olahraga}

Secara umum, kecemasan dapat dibagi dalam dua kategori, yakni state anxiety dan trait anxiety. Ketakutan yang tidak proporsional terhadap satu situasi tertentu disebut dengan state anxiety. Jenis kecemasan ini merupakan 
kondisi emosi yang bersifat sementara dan berlangsung untuk suatu situasi tertentu saja. Jenis kecemasan berikutnya adalah trait anxiety, jenis kecemasan yang lebih menetap dan menyebar ke berbagai aspek kehidupan individu. Individu merasa cemas, kapan dan sehingga timbul rasa khawatir dan tegang.

Terkait dengan olahraga, kecemasan yang timbul saat pertandingan merupakan reaksi emosional negatif atlet ketika harga dirinya dirasa terancam. Hal ini terjadi apabila atlet menganggap pertandingan sebagai tantangan berat untuk berhasil, mengingat kemampuan penampilannya. Kecemasan ini biasanya dipicu pula oleh karena atlet banyak memikirkan akibat dari kekalahannya. Kecemasan akan selalu terjadi pada diri individu apabila sesuatu yang diharapkan mendapat rintangan sehingga kemungkinan tidak tercapainya harapan menghantui pikirannya. Kecemasan olahraga adalah perasaan khawatir, gelisah, dan tidak tenang dengan menganggap pertandingan sebagai sesuatu yang membahayakan (Martens, Vealey, \& Burton, 1990).

Unsur yang paling dominan menyebabkan kecemasan adalah unsur kognitif yakni kekhawatiran dan pikiran negatif bahwa proses dan hasil pertandingan dapat mengancam posisi atlet (Smith \& Sarason, 1993). Anshel menjelaskan bahwa kecemasan olahraga menggambarkan perasaan atlet bahwa sesuatu yang tidak dikehendaki akan terjadi (1997). Hal yang tidak dikehendaki misalnya atlet tampil buruk, lawannya dipandang demikian superior, atlet akan mengalami kekalahan, kekalahan menyebabkan dirinya dicemooh oleh teman-teman dan seterusnya membentuk kecemasan berantai. Kondisi ini memberikan dampak yang sangat tidak menguntungkan pada atlet apalagi jika rasa percaya diri atlet kurang tinggi. Atlet cenderung tampil kaku, bingung, dan gerakangerakannya menjadi kurang terkontrol dengan baik. Spielbelger (1972) rnenerjemahkan kecemasan sebagai takut mengalami kegagalan (fear offailure) atau takut menderita kekalahan. Spielbelger juga mendefinnisikan pikiran negatif berhubungan dengan anggapan mengenai bahaya yang akan menimpa diri. Sroufe (1996) mengemukakan bahwa remaja yang berada pada masa menuju kematangan mempunyai kemungkinan yang besar untuk mengalami kecemasan. Pada masa ini, remaja digambarkan aktif 
menjelajahi berbagai pilihan untuk menentukan identitas diri. Mereka masih kebingungan untuk menentukan identitas yang sesuai dengan dirinya sehingga emosi mereka sangat labil. sebagai akibatnya mereka sering keliru menanggapi suatu situasi.

Hasil penelitian Cratty (1973) mengenai fluktuasi anxiety pada umurumur tertentu memperoleh simpulan bahwa: (a) anxiety akan memuncak pada usia sekitar dua puluh tahun (late adolescent years), (b) pada usia sekitar tiga puluh tahun, anxiety cenderung untuk menurun, dan (c) setelah usia enam puluh tahun, anxiety biasanya mulai naik lagi. Anxiety memuncak pada umur dua puluhan karena mendekati puncak-puncak potensi fisik (physical potentials) yaitu tahun paling produktif dalam karier seorang atlet.

Tidak dapat disangkal situasi pertandingan memberikan pengaruh yang menekan pada atlet. Reaksi tersebut sangat bergantung pada atlet yang bersangkutan. Pada atlet yang sensitif (peka), situasi ini dapat menimbulkan kecemasan. Sifat kecemasan olahraga juga berubah sesuai situasi pertandingan, yaitu sebelum, selama, dan mendekati akhir pertandingan. Hal ini sesuai dengan yang dikemukakan Cratty (1973) sebagai berikut. (a) Biasanya sebelum pertandingan, anxiety naik disebabkan oleh bayangan akan beratnya tugas atau pertandingan yang akan datang, (b) selama pertandingan, tingkat anxiety biasanya menurun karena atlet telah beradaptasi dengan situasi pertandingan, dan (c) mendekati akhir pertandingan, tingkat anxiety biasanya mulai naik kembali, terutama apabila skor pertandingan sama atau hanya berbeda sedikit saja. Dalam beberapa cabang olahraga yang durasinya berlangsung untuk waktu yang lama seperti menembak, panahan, dan beberapa nomor atletik, fluktuasi kecemasan atlet biasanya semakin tinggi.

\section{Strategi mengatasi kecemasan olahraga}

Kecemasan olahraga menjadi suatu masalah yang memerlukan jalan keluar. Hardy, Jones \& Gould (1991) mengemukakan bahwa pertandingan olahraga berlangsung dalam suatu lingkungan yang sangat menekan sehingga kemampuan mengawasi tekanan sangat penting. Para atlet boleh menggunakan berbagai strategi dan keterampilan untuk mengatasi situasisituas tersebut. Gunarsa (2004) menyatakan bahwa untuk membantu atlet 
yang mengalami kecemasan dapat digunakan pendekatan konseling yang sesuai dengan karakteristik atlet tersebut ataupun yang sesuai dengan permasalahannya. Setyobroto (1989) juga menyatakan bahwa untuk membantu memecahkan masalah kecemasan yang dihadapi atlet, dapat digunakan pendekatan psikologik dengan terapi konseling. Suinn (1990) menyarankan agar atlet diberi program konseling yang mengajarkan strategi mengatasi kecemasan. Kecemasan olahraga merupakan gangguan emosi yang dihadapi oleh atlet sehingga konseling sangat berperan dalam membantu atlet yang mengalami gangguan emosi dengan memberikan konseling berdasarkan pendekatan yang dapat dilaksanakan. Salah satu bentuk konseling adalah rational emotive behavior therapy.

\section{Perangkat instrumen kecemasan olahraga}

Beberapa instrument kecemasan olahraga yang telah dikembangkan untuk mengukur kecemasan atlet di antaranya adalah Taylor Manifest Anxiety Scale (TMAS), Autonomic Perception Questionnaire (APQ), Affective Adjective Checklist (AACL), Activation Deactivation Checklist (AD-ACL), Trait Anxiety Inventory (TAI), Sport Competition Anxiety Test (SCAT), State Anxiety Inventory (SAI), Competitive State Anxiety Inventory I (CSAI I), Competitive State Anxiety Inventory II (CSAI 11), dan Sport Anxiety Scale (SAS). Taylor Manifest Anxiety Scale (TMAS) dikembangkan tahun 1951 (sitat dalam, 1989). Tes ini terdiri atas 50 butir dengan alternatif jawaban ya/tidak. Instrumen ini juga dikembangkan untuk anak-anak yaitu Children Manifest Anxiety Scale (CMAS). Autonomic Perception Questionnaire (APQ) dikembangkan oleh Mendler dan Urviller (1958, sitat dalam Gunarsa, 1989) yang terdiri atas tiga bagian. Affective Adjective Checklist (AACL) dikembangkan oleh Zuckerman (1960, sitat dalam Gunarsa, 1989). Instrumen ini terdiri dari 21 butir (sebelas butir digolongkan sebagai kecemasan yang positif dan sepuluh butir digolongkan sebagai kecemasan yang negatif). Activation Deactivation Checklist (AD-ACL) dikembangkan Thayer (1967, sitat dalam Gunarsa, 1989) untuk mengukur aktivitas melalui empat dimensi yang independent. Trait Anxiety Inventory (TAI) dikembangkan oleh Spielbelger, Gorsuch, \&Lushene(1970, sitat dalam Gunarsa, 1989) untuk mengukur general non-transitory anxiety. Tes ini terdiri atas 20 butir. Sport Competition 
Anxiety Test (SCAT), ini dikenal untuk anak-anak dan untuk orang dewasa. Tes ini merupakan modifikasi dari TAI yang dikembangkan oleh Martens (sitat dalam Gunarsa, 1989) dan terdiri atas 15 butir. Jawaban tes dalam bentuk tiga skala Likert. State Anxiety Inventory (SAI) dikembangkan oleh Spielbelger (1970, sitat dalarn Gunarsa, 1989). SAI dan TAI untuk, trait-A dianggap sebagai tes pasangan. Tes ini terdiri atas 21 pertanyaan yang dinilai dengan kata: "Perasaan saya...." Tes ini menggunakan empat tipe skala Likert. Competitive State Anxiety Inventory I (CSAI I), dibuat berdasarkan penelitian Spielbelger (1970, sitat dalam Gunarsa, 1989). Lima butir dari dua puluh butir SAI dipakai sebagai sub-skala. CSAI yang terdiri atas sepuluh butir yang berasal dari tes induk lalu dimodifikasi oleh Martens. Competitive State Anxiety Inventory II (CSAI II) dikembangkan oleh Martens, Burton, Vealey, Smith, \& Bump (1981, sitat dalam Gunarsa, 1989). Instrumen ini mengukur aspek state-A yang multidimensional pada kompetisi (somatik, kognitif, dan rasa percaya diri). Pendekatan multidimensional memberi penjelasan yang lebih banyak tentang respon seorang atlet terhadap situasi kompetisi. Tes ini terdiri atas 27 butir dan dijawab dalam bentuk empat skala Likert. Terakhir, mengingat kebutuhan yang jelas bagi suatu ukuran multidimensi dari kecemasan kompetisi olahraga yang membedakan aspek kognitif dari somatik (badan) berdasarkan konsep tersebut, Smith, Smoll, \& Schutz (1990) mengembangkan skala kecemasan olahraga (Sport Anxiety Scale, SAS).

Di antara kesepuluh contoh instrument yang ada, SAS dinilai sebagai yang paling sesuai dengan penelitian kali ini, karena terkait langsung dengan pengukuran kecemasan subjek. Penyusunan SAS berawal dengan serangkaian kajian analisis faktor. Smith etal (1990) memberikan suatu versi tiga puluh butir dari skala itu pada atlet SMU pria dan wanita $(\mathrm{N}=451)$ dan pada suatu sampel lepas para pemain football antar-kampus (N=123). Hasil analisis komponen-prinsip (principal-components, PC) penjajakan terpisah atas kedua himpunan data menemukan tiga faktor yang serupa. Meskipun analisis-analisis penyelidikan ini menghasilkan faktorfaktor yang bisa ditafsirkan, delapan soal yang bermasalah dihapus dari skala tersebut. Smith etal. (1990) kemudian memberikan ulang versi tiga puluh soal dari SAS tersebut pada 384 atlet dari sampel SMU semula dan 
memberikan suatu versi 22 soal terevisi dari skala tersebut kepada suatu sampel terpisah yang terdiri etas 490 atlet SMU. Dengan menggunakan serangkaian analisis faktor penegasan (confirmatory factor analyses/CFA) kemungkinan maksimum, Smith etal. (1990) menemukan bahwa solusi yang paling cocok diberikan oleh suatu versi 21 soal yang terdiri atas tiga faktor dari skala tersebut. Versi akhir SAS terdiri dari suatu sub-skala kecemasan somatic sembilan soal, sub-skala kecemasan sembilan soal, dan suatu sub-skala gangguan konsentrasi tiga soal. Tingkat-tingkat konsistensi internal yang dapat diterima menurut Cronbach (1951, sitat dalam Dunn, Wilson, \& Syrotuik, 2000) bagi semua sub-skala dilaporkan oleh Smith etal. (1990) dari analisis-analisis terpisah atas kedua kumpulan data CFA: kecemasan somatik 0,880 dan O.920; khawatir, 0,820 dan 0,860; serta gangguan konsentrasi, 0,074 dan 0,810.

Meskipun SAS diakui sebagai instrumen competitive trait anxiety (CTA) pilihan di kalangan banyak psikolog olahraga tetapi para ahli psikometrik telah berulang-ulang memperingatkan para peneliti untuk hati-hati dalam menyimpulkan bahwa struktur faktor dan kompos isi faktor suatu instrumen itu konsisten antar-sampel, sebelum pengulangan atas usahausaha analisis faktor aslinya dilakukan (Gorsuch, 1983; Messick 1989; Pedhazur \& Schmelkin, 1991). Gauvin dan Russel (1993) juga menganjurkan para peneliti psikologi olahraga mengulang bukti validitas asli mengenai alat pengukuran sebelum berlanjut menggunakan alat tersebut dalam situasi-situasi riset, sekalipun tidak ada perbedaan budaya atau bahasa antara sampel-sampel validitas aslinya dan populasi sasaran yang dipilih. Mengingat keterbatasan ketersediaan bukti-bukti empiris yang terbatas yang mendukung komposisi dan struktur faktor SAS, tampaknya masuk akal untuk mengisyaratkan bahwa dibutuhkan lebih banyak bukti validitas mengenai struktur laten dari instrumen tersebut. Dunn et al, (2000) telah melakukan studi untuk menyelidiki dan memastikan komposisi dan struktur faktor dari SAS menggunakan tiga kumpulan data yang diperoleh dalam proyek-proyek riset mandiri. Sekalipun hasil yang diperoleh cukup memuaskan, tetapi instrumen tersebut belum tentu dapat mengukur kecemasan olahraga di Indonesia secara valid dan reliabel, karena belum tentu sesuai dengan karakteristik kepribadian atlet Indonesia. 
Oleh karena itu, penulis ingin mencoba mengembangkan instrumen kecemasan olahraga yang valid dan reliabel untuk atlet Indonesia.

\section{Metode Penelitian}

\section{Variabel}

Variabel penelitian adalah kecemasan olahraga. Kecemasan olahraga didefinisikan sebagai keadaan cemas, gelisah, dan tidak tenang dengan menganggap pertandingan sebagai sesuatu yang membahayakan. Dalam penelitian ini, kecemasan olahraga diwakili dengan skor angket kecemasan olahraga hasil adaptasi dari tes SAS. Instrumen ini meliputi empat aspek kecemasan olahraga, yaitu: motorik, afektif, somatik, dan kognitif.

\section{Instrumen}

Instrumen ini merupakan sejumlah butir pernyataan yang menggambarkan gejala dan gangguan kognitif, afektif 'somatik, dan motorik yang dialami atlet saat menghadapi pertandingan; gejala dan gangguan ini merupakan indikasi kecemasan, serta skala kecemasan olahraga ini dirancang dalam bentuk self report (laporan diri) (Stodolsky, 1985). Tujuannya ialah agar subjek mengungkapkan pikiran dan perasaannya sesegera mungkin setelah menghadapi pertandingan.

\section{Populasi dan Sampel}

Penelitian ini melibatkan para atlet dari enam klub sepakbola pemula Kota Banda Aceh. Jumlah total subjek penelitian adalah 406 atlet dan 6 orang pelatih. Rincian subjek penelitian adalah sebagai berikut. Tahap wawancara sebanyak 18 atlet dan 6 orang pelatih, tahap grup nominal sebanyak 84 atlet, tahap Q-sort sebanyak 8 orang ahli, dan tahap uji coba satu sebanyak 406 atlet klub sepakbola pemula Kota Banda Aceh. Uji coba tahap kedua dilakukan pada atlet klub sepakbola pemula Provinsi Aceh, dengan populasi yang terdiri atas 32 klub dan sejumlah 1860 atlet. Subjek uji coba tahap kedua hanya 15 klub dengan 1000 atlet. Pemilihan subjek penelitian dilakukan, dengan teknik pengambilan subjek berumpun (clustered sampling) dengan teknik purposive sampling, yaitu berdasarkan prestasi klub 
yang baik, tingginya frekuensi mengikuti liga, dan manaiemen klub yang baik.

\section{Prosedur Pengembangan}

Dalam penelitian ilmiah ada tiga jenis instrumen yang paling sering dipakai, yaitu angket, tes dan skala nilai (Hadi, 1991:1). Lebih lanjut Hadi menjelaskan: "Angket digunakan untuk menyelidiki pendapat subjek mengenai hal atau untuk mengungkapkan keadaan pribadi responden. Tes digunakan untuk mengungkapkan karakteristik individu, khususnya kemampuan, bakat, minat, sikap dan kepribadian." Skala nilai digunakan untuk menilai keadaan pribadi orang lain atau mengenai sesuatu hal tertentu, Berdasarkan penjelasan tersebut, ketiga bentuk instrument baik tes, angket maupun skalai nilai memiliki kesamaan, terutama dari tujuan penelitian. Oleh sebab itu, instrumen kecemasan olahraga sepakbola pemula Kota Banda Aceh berisi pernyataan dengan skala penilaian berkisar 1 (satu) sampai 4 (empat) sesuai model yang dikembangkan oleh Likert. Penggunaan skala nilai 1 sampai 4 diharapkan dapat memamahi salah satu persyaratan panting yang harus dimiliki oleh suatu instrumen penelitian yaitu ketelitian, di samping kesahihan dan keterandalan (Hadi, 1991).

Atlet diminta untuk merespon butir pernyataan itu sesuai dengan yang dialaminya dengan memilih butir yang paling sesuai dengan dirinya pada saat menghadapi pertandingan. Alternatif jawaban responden telah ditentukan dengan menggunakan skala Likert yakni; "Sangat Sesuai (SS), Sesuai (S), Agak Sesuai (AS), dan Tidak Sesuai (TS)." Pemberian skor untuk skala kecemasan olahraga disesuaikan dengan jawaban butir pertanyaan, yakni: $\mathrm{SS}=4, \mathrm{~S}=3, \mathrm{AS}=2$, $\mathrm{TS}=1$. Penentuan tingkat kecemasan tes didasarkan pada skor yang tercantum pada Tabel 1.

Tabel 1. Klasifikasi Tingkat Kecemasan Berdasarkan Skor Setiap Skala

\begin{tabular}{|l|c|c|c|c|}
\hline Jenis Instrumen & & \multicolumn{2}{|c|}{ Tingkat Kecemasan } & \\
\hline & Rendah & Agak Rendah & Agak Tinggi & Tinggi \\
\hline $\begin{array}{l}\text { Skala Kecemasan } \\
\text { Olahraga }\end{array}$ & $1-22$ & $23-44$ & $45-66$ & $67-88$ \\
\hline
\end{tabular}

334 - Jurnal Penelitian dan Evaluasi Pendidikan Tahun 16, Nomor 1, 2012 
Prosedur pengembangan instrumen pada penelitian ini mengikuti Costin (1989) yang mengemukakan, bahwa kecemasan mempengaruhi aspek kepribadian individu dan bersifat: cognitive (cognitively), affective (affectively), somatic (somatically), dan motoric (motorically). Upaya ini terbagi menjadi dua tahap, yaitu: (1) mengadaptasi instrumen Sport Anxiety Scale (SAS) yang dikembangkan oleh Smith, Smoll, dan Schutz (1990), dan (2) proses pengumpulan butir baru.

\section{Adaptasi instrumen}

Proses adaptasi terhadap instrumen SAS yang dikembangkan oleh Smith, Smoll, dan Schutz (1990) melalui dua tahap, yaitu: menerjemahkan instrumen tersebut ke dalam bahasa Indonesia dan meminta bantuan teman sejawat untuk memeriksa terjemahan tersebut, selanjutnya mengonsultasikan hasil terjemahan tersebut kepada ahli.

\section{Pengumpulan butir-butir baru (item pool)}

Pengumpulan butir baru dilakukan sebagaimana telah disarankan oleh Mutohir (1986, 1987, 1994). Pengumpulan butir-butir baru meliputi empat tahap, yaitu: (a) pengumpulan bakal butir, (b) pemilihan butir butir, (c) penyusunan skala, dan (d) penguji cobaan instrumen.

Pengumpulan bakal butir. Bakal bulir dikumpulkan melalui dua cara, yaitu wawancara dan proses grup nominal. Teknik wawancara meliputi studi pendahuluan terhadap 18 orang atlet dan 6 orang pelatih klub sepakbola pemula Kota Banda Aceh. Untuk mempermudah teknik wawancara, peneliti membuat panduan wawancara. Wawancara tersebut bertujuan mengenali gejala dan gangguan yang dialami atlet saat menghadapi pertandingan. Hasil wawancara dicatat dan digunakan untuk melengkapi teknik proses grup nominal.

Pengumpulan bakal butir kedua dilakukan dengan teknik proses grup nominal. Teknik ini dikembangkan oleh Delbecq dan Vande Ven sejak 1971. Teknik ini memberi kesempatan kepada setiap peserta diskusi untuk berpartisipasi aktif secara bergantian sesuai giliran. Setiap peserta diminta menuliskan pendapat mereka pada secarik kertas. Pendapat ini akan dinilai oleh setiap anggota kelompok secara anonim untuk menjamin kebebasan berpendapat (Sample, 1984). 
Teknik grup nominal dilakukan pada atlet sepakbola pemula Kota Banda Aceh yang berjumlah 84 atlet atau 20 persen dari seluruh jumlah atlet klub sepakbola pemula Kota Banda Aceh. Langkah-langkah teknik grup nominal dalam mengumpulkan bakal butir telah disederhanakan Mutohir (1987) menjadi dua tahap. Tahap pertama, para atlet dikumpulkan dalam satu ruangan dan mereka masing-masing diminta untuk menulis pada kertas yang disediakan tentang gejala serta gangguan yang dialami atlet saat menghadapi pertandingan. Tahap kedua, hasil adaptasi dan hasil wawancara dengan atlet dan pelatih digunakan dalam proses diskusi kelompok. Hasil wawancara selanjutnya diklasifikasi secara bersama antara peneliti dengan anggota grup Q-sort menurut empat sub-dimensi yang telah ditentukan sebelumnya.

Pemilihan butir-butir (screening of item pool) dengan teknik Q-sort. Sesuai dengan pendapat Mutohir (1986, 1987, 1994), proses pemilihan butir (screening process of item pool) dilakukan untuk mereduksi butir-butir yang mencerminkan gejala dan gangguan kecemasan olahraga. Untuk seleksi butir dilakukan dengan kegiatan "Q-sort" dan "analisis faktor." Kegiatan Q-sort dilakukan melalui pengumpulan setiap butir dan ditulis dalam kertas ukuran 5 x $5 \mathrm{~cm}$. Prosedur kegiatan Q-sort adalah: (1) menentukan anggota kelompok Q-sort (peneliti dibantu oleh 8 orang dosen FKIP Unsyiah, 5 orang dosen jurusan pendidikan olahraga dan 3 orang dosen jurusan pendidikan bimbingan konseling), (2) pemberian penjelasan tentang pengertian dan tujuan Q-sort kepada para anggota, dan (3) penyaringan butir-butir oleh anggota kelompok untuk setiap dimensi menjadi tiga kategori menurut kepentingannya, yaitu: "amat penting", "cukup penting", dan "tidak penting." Kriteria penyaringan adalah kejelasan dimensi yang diwakili dan penilaian derajat kepentingan butir oleh mayoritas anggota grup Q-sort $(>60 \%)$. Melalui tahap ini, diperoleh dan disepakati 54 gejala dan gangguan kecemasan olahraga yang dinilai paling penting.

Penyusunan skala (construction of scales). Instrumen yang dikembangkan pada penelitian ini diharapkan dapat berfungsi sebagai diagnostic feedback sehingga sekalipun memiliki cakupan yang luas, instrumen tersebut tetap harus memuat butir-butir spesifik untuk dapat mengukur gejala dan gangguan yang dialami atlet sewaktu bertanding secara reliabel dan valid. 
Oleh sebab itu instrumen disusun melalui prosedur-prosedur tertentu sehingga dapat dipertanggungjawabkan secara ilmiah, baik adaptasi, pengumpulan butir, seleksi butir, uji coba dan penyusunan skala penilaian.

Penguji-cobaan skala. Pada tahap awal, dilakukan penetapan dimensionalitas instrumen melalui factorial validity. Tahap ini bertujuan mengenali faktor-faktor utama yang merupakan gejala dan gangguan kecemasan olahraga menurut atlet. Penyusunan skala meliputi: (1) analisis butir, (2) reliabilitas instrumen, (3) analisis factor, dan (4) penyusunan skala penilaian. Semua tahapan tersebut bertujuan untuk menghasilkan instrumen handal untuk mengungkap tingkat kecemasan olahraga.

\section{Analisis data}

Data yang telah dikumpulkan selanjutnya dikategorikan dan dianalisis baik secara kualitatif maupun kuantitatif. Data kualitatit digunakan agar dapat lebih menjelaskan permasalahan yang dibahas secara naratil. Sedangkan data kuantitatif dianalisis dengan menggunakan teknikteknik statistik.

Butir-butir yang dikumpulkan sebagai indikator gejala dan gangguan kecemasan yang telah diperoleh melalui adaptasi, wawancara, proses grup, seleksi dan kategori dengan menggunakan Q-sort akan menjadi butir-butir yang digunakan dalam proses uji coba. Selanjutnya hasil uji coba instrumen dianalisis dengan teknik statistik berikut ini (a) Analisis reliabilitas dengan menggunakan Alpha Cronbach, (b) Analisisi faktor analisis dengan menggunakan, "teknik Principal Axis Factoring dan Rotation Method Oblimin with Kaiser Normalization." Seluruh analisis dilakukan dengan menggunakan bantuan komputer melalui program Statistical Package for Social Sciences (SPSS) (Nie, 1975).

\section{Prosedur pelaksanaan}

Penelitian pengembangkan alat ukur kecemasan olahraga dilaksanakan pada atlet dan pelatih sepakbola pemula di Provinsi Aceh. Waktu pelaksanaannya mulai bulan Mei sampai Oktober 2011, dengan rincian waktu pelaksanaan, yakni tahap observasi dilaksanakan pada bulan Mei 2011, tahap wawancara, teknik grup nominal, Q-sort, dan uji coba dilaksanakan pada bulan September sampai Oktober 2011. 
Adapun prosedur pelaksanaan penelitian, peneliti menghubungi pelatih semua klub yang menjadi subjek penelitian untuk memperoleh izin untuk mendekati pemain mereka untuk ikut dalam penelitian ini. Keikutsertaan ini bersifat sukarela dan persetujuan tertulis diperoleh dari tiap atlet sebelum pengumpulan data. Peneliti melakukan pertemuan dengan atlet sesuai dengan jadwal yang ditentukan oleh masing-masing pelatih. Selanjutnya peneliti melakukan tahap-tahap, yakni wawancara, grup nomimal, Q-sort, dan pernbagian skala kecemasan olahraga kepada subjek pada tahap uji coba.

\section{Hasil uji ooba instrumen}

Berdasarkan hasil pengolahan data, dari 54 butir pernyataan ternyata ada delapan butir pernyataan yang tidak memiliki konsistensi internal. Dengan demikian delapan butir tersebut tidak diikutsertakan ke dalam instrumen penelitian, sehingga instrumen penelitian ini hanya terdiri atas 46 butir pernyataan. Beberapa butir yang tidak diikutsertakan dalam alat ukur penelitian ini adalah butir 5 (sering mencabut-cabut rambut), 8 (sering mengatup geraham), 19 (merasa kehilangan energi), 24 (memikirkan tentang tampilan buruk), 42 (menjadi pendiam), 43 (banyak berbicara), 50 (sering mengigit bibir), dan 54 (merasa tidak nyaman). Estimasi reliabilitas dengan menggunakan formula Alpha Cronbach menunjukkan, bahwa keempat faktor memiliki koefisien reliabilitas antara 0,531 sampai dengan 0,856, yang dikategorikan cukup baik sampai baik.

Setelah diadakan uji coba, diperoleh 46 butir pernyataan dalam satu instrumen. Selanjutnya ke-46 butir pernyataan tersebut dijadikan instrumen untuk mengukur tingkat kecemasan atlet klub sepakbola pemula di Provinsi Aceh. Hasil uji coba tahap kedua instrumen kecemasan olahraga dikenakan pada subjek 1000 atlet pada atlet klub sepakbola Provinsi Aceh, selanjutnya dianalisis kembali. Hal ini untuk menjawab apakah instrumen kecemasan olahraga yang dikembangkan pada atlet klub sepakbola pemula Kota Banda Aceh dapat digunakan oleh atlet secara reliabel? Data hasil uji coba tahap kedua dianalisis dengan menggunakan estimasi reliabilitas. Hasil analisis tersebut sebagai berikut. 
Tabel 2. Muatan faktor keempat puluh satu butir instrumen

\begin{tabular}{|c|c|c|c|}
\hline Keterangan & $\begin{array}{l}\text { Muatan factor }> \\
0,300 \text { \& hanya } \\
\text { muatan muncul } \\
\text { pada satu faktor }\end{array}$ & $\begin{array}{l}\text { Muatan Faktor }> \\
0,300 \text { tetapi } \\
\text { muncul pada } \\
\text { beberapa faktor }\end{array}$ & $\begin{array}{l}\text { Muatan faktor }> \\
0,300\end{array}$ \\
\hline $\begin{array}{l}\text { Nomor } \\
\text { Butir }\end{array}$ & $\begin{array}{l}52,18,13,35,39, \\
32,36,28,29,25, \\
21,48,1,26,22,31, \\
41,23,49,20,47, \& \\
9\end{array}$ & $\begin{array}{l}30,11,6,40,51, \\
38,10,27,33,2, \\
12,45, \\
53, \& 46\end{array}$ & $\begin{array}{l}34,17,15,16, \& \\
7\end{array}$ \\
\hline
\end{tabular}

Berdasarkan hasil pengolahan data, ternyata 46 butir pernyataan seluruhnya memiliki konsistensi inetrnal yang baik. Keempat puluh enam butir tersebut diikutsertakan dalam instrumen penelitian. Oleh karena, nilai probabilitas ke 46 butir tersebut lebih kecil dari 0,05. Adapun estimasi reliabilitas dengan menggunakan formula Alpha Cronbach menunjukkan, bahwa keempat faktor memiliki koefisien reliabilitas dengan alpha antara antara 0,631 sampai dengan 0,823. Oleh sebab itu, instrumen tersebut dinilai dapat memberikan hasil yang dapat dipercaya (andal), untuk selanjutnya melalui proses analisis faktor.

Uji KMO and Bartlett's Test. Uji KMO and Bartlett's test dilakukan untuk mengetahui apakah variabel dan sampel yang ada dapat dianalisis lebih lanjut atau tidak. Adapun hasil uji $\mathrm{KMO}$ and Bartlett's test adalah 0,734 dengan signifikansi $\mathrm{p}<0,001$. Oleh karena angka tersebut sudah di atas 0,50 dan signifikansi jauh di bawah 0,05 , variabel dan sampel yang ada dapat dianalisis lebih lanjut.

Uji anti-image matrices. Uji anti-image matrices atau anti-image correlation dilakukan untuk mengetahui butir yang masuk dalam faktor dan butir yang tidak masuk dalam faktor. Adapun hasil uji anti-image correlation ternyata dari empat puluh enam butir yang ada hanya empat puluh satu butir yang masuk dalam faktor dan lima butir tidak masuk dalam faktor, antara lain adalah butir-butir 3 (mudah jengkel), 4 (kurang bergairah), 14 (pesimis), 37 
(khawatir tentang pencapaian tujuan), dan 44 (merasa malu). Hal ini disebabkan hasil measure of'sampling adequacy yang diperoleh lebih kecil dari pada 0,50 .

\section{Tabel 3. Hasil Uji Pattern Matrix}

\begin{tabular}{|c|c|c|c|c|c|}
\hline \multirow[b]{2}{*}{ Butir } & & \multicolumn{4}{|c|}{ Faktor } \\
\hline & & $\begin{array}{c}1 \\
\text { Motorik }\end{array}$ & $\begin{array}{c}2 \\
\text { Afektif }\end{array}$ & $\begin{array}{c}3 \\
\text { Somatik }\end{array}$ & $\begin{array}{c}4 \\
\text { Kognitif }\end{array}$ \\
\hline 25. & Cepat putus asa & & 0,666 & & \\
\hline 21. & Sembrono. & & 0,671 & & \\
\hline 48. & Memiliki keraguan diri & & 0,694 & & \\
\hline 1. & Jantung berdebar-debar keras & & & 0,343 & \\
\hline 26. & Selalu ingin buang air kecil & & & 0,631 & \\
\hline 22. & Mengalami ketegangan & & & 0,733 & \\
\hline 31. & Pernafasan tidak teratur & & & 0,738 & \\
\hline 41. & Sering minum air & & & 0,881 & \\
\hline 23. & Berkeringat dingin & & & 0,711 & \\
\hline 49. & Suka tidur & & & 0,799 & \\
\hline 20. & $\begin{array}{l}\text { Memikirkan tidak bisa } \\
\text { berkonsentrasi }\end{array}$ & & & & 0,567 \\
\hline 47. & $\begin{array}{l}\text { Berpikir tentang hal tidak } \\
\text { berhubungan. }\end{array}$ & & & & 0,496 \\
\hline 9. & $\begin{array}{l}\text { Pikiran negatif mengganggu } \\
\text { konsentrasi }\end{array}$ & & & & 0,364 \\
\hline 52. & Raut muka dan dahi berkerut. & 0,695 & & & \\
\hline 18. & Gemetar & 0,933 & & & \\
\hline 13. & Kaki terasa berat & 0,497 & & & \\
\hline 35. & Sering menggaruk-garuk kepala & 0,676 & & & \\
\hline 39. & Otot-otot sakit & 0,794 & & & \\
\hline 32. & Sering jalan mondar-mandir. & 0,632 & & & \\
\hline 36. & Badan lesu & 0,339 & & & \\
\hline 28. & Tubuh terasa kaku & 0,722 & & & \\
\hline 29. & $\begin{array}{l}\text { Mengalami ketegangan otot } \\
(\mathrm{kram})\end{array}$ & 0,562 & & & \\
\hline
\end{tabular}

Extraction Method: Principal Axis Factoring

Rotation Method: Oblimin with Kaiser Normalization 
Berdasarkan hasil analisis faktor dari 41 yang tersebar menjadi empat faktor, ternyata dari beberapa kali melakukan analisis faktor, hanya 22 butir yang memiliki muatan faktor lebih besar dari 0,30 pada pattern matrix dan sekaligus hanya muncul pada satu faktor. Terdapat enam butir memiliki muatan faktor lebih kecil dari 0,30 pada pattern matrix. Selain itu, terdapat pula 13 butir yang memiliki muatan faktor lebih besar dari 0,30 tetapi muncul pada beberapa faktor. Butir-butir yang memiliki muatan faktor lebih kecil dari 0,30 dan muncul pada beberapa faktor digugurkan. Hasil akhir dapat dilihat pada Tabel 3 yang telah tersaji di atas.

Factor correlation matrix. Nilai-nilai yang diperoleh dari korelasi berdasarkan nilai analisis faktor, terlihat dengan jelas bahwa muatan faktor dari 22 butir yang terdistribusi pada 4 faktor dan masing-masing butir bermuatan secara signifikan pada faktor yang ditargetkan untuk diukur. Tampak faktor-faktor dalam Skala kecemasan olahraga saling berkorelasi satu dengan yang lain, walaupun secara analisis faktor masing-masing faktor tampak jelas mengukur dimensi kecemasan yang harus diukur. Adapun factor correlation matrix hasil analisis faktor dapat dilihat pada Tabel 4.

Tabel 4. Hasil factor correlation matrix

\begin{tabular}{|c|l|c|c|c|c|}
\hline \multicolumn{2}{|l|}{ Faktor } & $\begin{array}{c}1 \\
\text { Motorik }\end{array}$ & $\begin{array}{c}2 \\
\text { Afektif }\end{array}$ & $\begin{array}{c}3 \\
\text { Somatic }\end{array}$ & $\begin{array}{c}4 \\
\text { Kognitif }\end{array}$ \\
\hline 1 & Motorik & 1,000 & 0,481 & 0,417 & 0,508 \\
\hline 2 & Afektif & 0,481 & 1,000 & 0,424 & 0,403 \\
\hline 3 & Somatik & 0,417 & 0,424 & 1,000 & 0,412 \\
\hline 4 & Kognitif & 0,508 & 0,403 & 0,412 & 1,000 \\
\hline
\end{tabular}

Extraction Method: Principal Axis Factoring

Rotation Method: Oblimin with Kaiser Normalization 


\section{Hasil Penelitian}

Secara singkat, pengembangan instrumen kecemasan olahraga ini melalui dua kegiatan, yakni kegiatan adaptasi dan kegiatan pengumpulan butir-butir baru dengan langkah-langkah sebagai berikut: (1) wawancara, (2) grup nominal, dan (3) grup Q-sort. Selanjutnya instrumen tersebut diuji cobakan sebanyak dua tahap, yakni uji coba satu dan uji coba dua. Hasil uji coba selanjutnya dianalisis dengan menggunakan pengujian validitas, reliabilitas, dan analisis faktor.

Berdasarkan hasil analisis, dapat dilihat faktor dan butir yang mencerminkan faktor-faktor gejala dan gangguan kecemasan olahraga yang diikutsertakan dalam skala kecemasan olahraga adalah sebagai berikut.

Faktor motorik. Berdasarkan hasil pengujian validitas, pengujian reliabilitas, dan analisis faktor hanya sembilan gejala dan gangguan dari faktor motorik yang mencerminkan gejala dan gangguan kecemasan olahraga yang diikutsertakan dalam skala kecemasan olahraga. Adapun gejala dan gangguan kecemasan olahraga tampak pada diri atlet melalui keadaan raut muka dan dahi berkerut, gemetar, kaki terasa berat, sering menggaruk-garuk kepala, otot-otot sakit, sering jalan mondar-mandir, badan lesu, tubuh terasa kaku, dan mengalami ketegangan otot. Faktor motorik adalah faktor pertama dalam kecemasan olahraga dengan korelasi antara skor butir dengan skor faktor terletak pada rentang 0,946 sampai 0,358 .

Faktor afektif. Berdasarkan hasil pengujian, validitas, pengujian reliabilitas, dan analisis faktor hanya tiga gejala dan gangguan dari faktor afektif yang mencerminkan gejala dan gangguan kecemasan olahraga yang diikutsertakan dalam skala kecemasan olahraga. Adapun gejala dan gangguan kecemasan olahraga tampak pada diri atlet melalui pengakuan atlet seperti merasa cepat putus asa, sembrono, dan memiliki keraguan diri. Faktor afektif adalah faktor kedua dalam kecemasan olahraga dengan korelasi antara, butir dengan skor faktor terletak pada rentang 0,773 sampai 0,654 .

Faktor somatik. Berdasarkan hasil pengujian validitas, pengujian reliabilitas, dan analisis faktor hanya tujuh gejala dan gangguan dari faktor 
somatik yang mencerminkan gejala dan gangguan kecemasan olahraga yang diikutsertakan dalam skala kecemasan olahraga. Adapun gejala dan gangguan kecemasan olahraga tampak pada diri atlet dalam keadaan jantung berdebar-debar keras, ingin buang air kecil, mengalami ketegangan, pemafasan tidak teratur, sering minum air, berkeringat dingin, dan sukar tidur. Faktor somatik adalah faktor ketiga dalam kecemasan olahraga dengan korelasi antara skor butir dengan skor faktor terletak pada rentang 0,861 sampai 0,392.

Faktor kognitif. Berdasarkan hasil pengujian validitas, pengujian reliabilitas, dan analisis faktor hanya tiga gejala dan gangguan dari faktor kognitif yang mencerminkan gejala dan gangguan kecemasan olahraga yang diikutsertakan dalam skala kecemasan olahraga. Adapun gejala dan gangguan kecemasan olahraga tampak pada diri atlet dalam wujud tidak bisa berkonsentrasi, berpikir tentang hal-hal yang tidak berhubungan, dan pikiran negatif yang mengganggu konsentrasi. Faktor kognitif termasuk faktor keempat dalam kecemasan olahraga dengan korelasi antara skor butir dengan skor faktor terletak pada rentang 0,501 sampai 0,334.

Berdasarkan hasil reduksi, pengujian validitas, pengujian reliabilitas, dan analisis faktor, dapat disimpulkan dari sekian banyak butir yang dirancang untuk skala kecemasan olahraga setelah melalui reduksi dan analisis statistik hanya 22 butir pernyataan yang terdiri atas 4 faktor yang dapat dipakai untuk skala kecemasan olahraga yang memiliki tingkat kesahihan yang sedang serta memiliki tingkat keterandalan yang tinggi.

Di samping itu, mengingat kebutuhan yang jelas terhadap aspek multidimensi suatu instrumen yang bisa membedakan aspek-aspek kecemasan olahraga, skala ini disusun atas empat dimensi kecemasan olahraga, yakni dimensi motorik, dimensi afektif, dimensi somatik, dan dimensi kognitif. Adapun skala kecemasan olahraga (SKO) tersebut di bawah ini. 
Tabel 5. Skala kecemasan olahraga

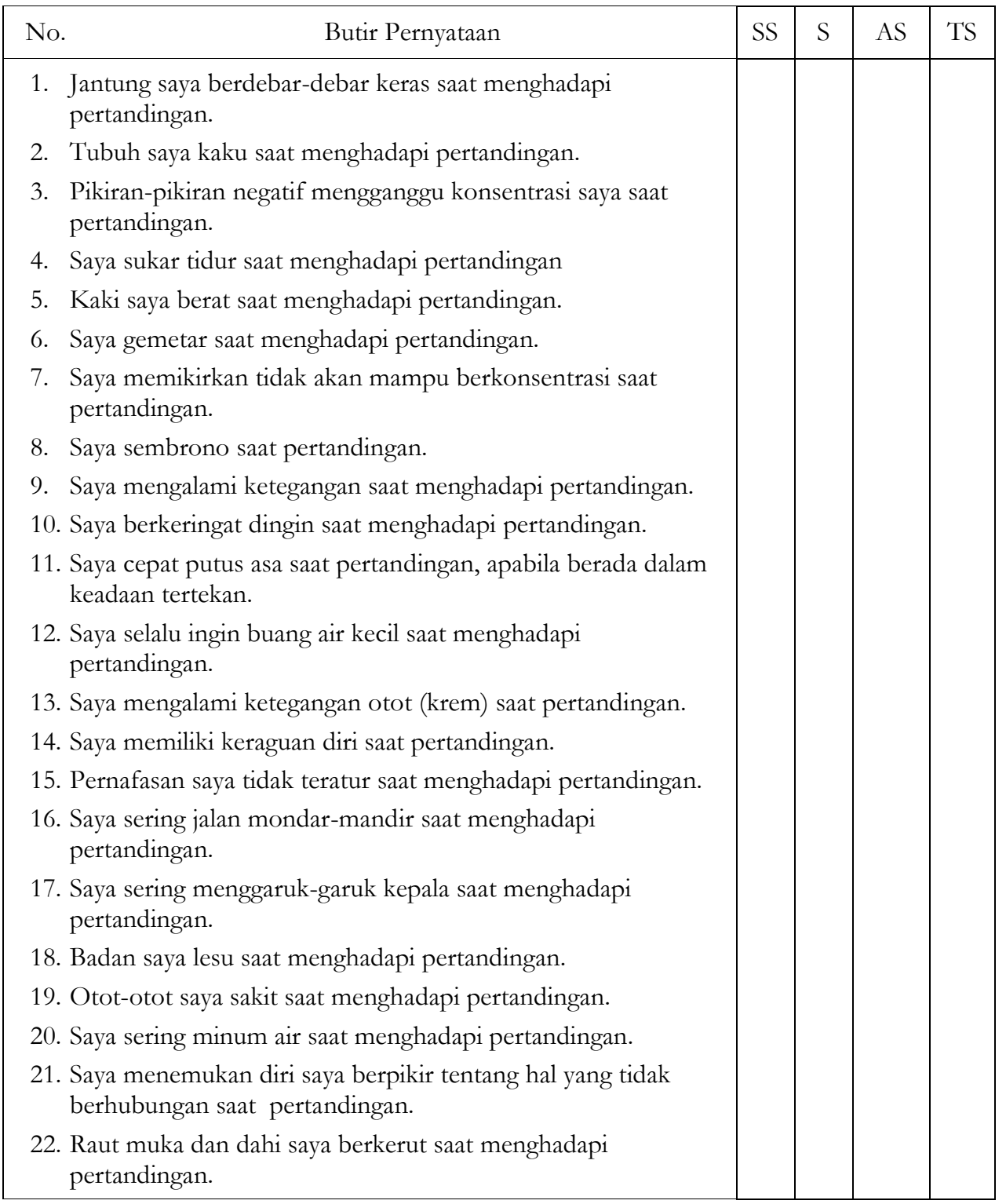

344 - Jurnal Penelitian dan Evaluasi Pendidikan Tahun 16, Nomor 1, 2012 


\section{Simpulan}

Hasil penelitian kali ini menunjukkan bahwa skala kecemasan olahraga yang terdiri atas empat faktor dan 22 butir pernyataan sudah dapat dinilai valid dan reliabel untuk mengukur kecemasan olahraga. Instrumen kecemasan olahraga yang dikembangkan di Provinsi Aceh sudah memperoleh replikasi kelayakan dan keandalan. Bagaimanapun juga instrumen kecemasan olahraga tersebut masih perlu dikembangkan dan diujicobakan kepada subjek yang berbeda sehingga benar-benar memperoleh implikasi kelayakan dan keandalan untuk digunakan pada situasi penelitian yang lebih luas.

Penelitian pengembangan instrumen kecemasan olahraga ini masih memiliki beberapa kelemahan, antara lain adalah: (1) analisis faktor yang masih terbatas pada tahap penggunaan analisis faktor penyelidikan (exploratory factor analyses/ EFA), belum sampai pada tahap analisis faktor penegasan (confirmatory factor analyses/CFA), dan (2) pelaksanaan uji coba tahap satu dan dua seharusnya dilakukan setelah menghadapi pertandingan (subjek harus bertanding sebelum menjawab angket), tetapi dalam pelaksanaannya subjek curna dikondisikan untuk mereview kembali tentang gejala dan gangguan yang subjek rasakan saat menghadapi lawan yang paling tangguh.

\section{Daftar Pustaka}

Anshel, M.H. 1997. Sport psychology: From theory to practice. Scottsdale, AZ:Gorsuch Scarisbrick.

Cratty, B.J. 1973. Psychology in contemporary, sport. New Jersey: Prentice Hall, Inc.

Costin, F. \& Draguns, J. G. 1989. Abnormal psychology: Patterns, issues, and inventions. New York: John Wiley \& Sons.

Dunn, J. G. H., Wilson, P., \& Syroruik, D. G. 2000. Reexamining the factorial composition and factor structure of the sport anxiety scale. Journal of Sport and Exercise Pscyhology, 22,183-193.

Gorsuch. R. L. 1983. Factor analyses (2"led.). Hillsdale. NJ: Erlbaum

$$
\begin{gathered}
\text { Pengembangan Alat Ukur Kecemasan Olahraga - } 345 \\
\text { Nyak Amir }
\end{gathered}
$$


Gunarsa, S.D. 1989. Psikologi olahraga. Jakarta: PT. Gunung Mulia.

Gunarsa, S.D. 2004, 8 Mei. Latihan mental terlupakan [on-line]. Diambil 8 Juli 2004, dari http://www.kompas.com/kompas\%2Dcetak/0405/08/or/10 13124.htm

Hadi, S. 1991. Analisis butir untuk instrumen angket tes dan skala nilai dengan Basic. Yogyakarta: Andi Offset.

Hardy, L., Jones, G., \& Gould, D. 1996. Understanding psychology preparation for sport: Theory and practice of elite performers. Chichester: Wiley.

Martens, R., Vealey, R. S. \& Burton, D. 1990. Competitive Anxiety in Sport. Champaign, Illinois: Human Kinetics.

Messick, S. 1989. Validity. In R.L. Linn (Ed.). Education measurement (3rd ed., pp. 1317). New York: Amereican Council on Education.

Mutohir, T. C. 1986. The Development and examination of student evaluation of teaching a effectiveness in an Indonesian higher education setting. Thesis, unpublished, Australia Macquarie University, Sydney.

Mutohir, T. C. 1987. Laporan penelitian pengembangan instrumen evaluasi efektifitas pengajaran di perguruan tinggi (suatu rintisan). Surabaya, Pusat Penelitian IKIP Surabaya, Depdikbud.

Mutohir, T. C. 1994. Evaluasi keefektivan pengajaran studi kasus di IKIP Surabaya.

Nie, N_ H., Hull, C. H., Jenkins. J.G., Steinbrenner, ' K., \& Bent, D. H. 1975. Statistical package for social sciences. New York: McGraw-Hill.

Pedhazur, E.J. \& Schmelkin, L.P. 1991. Measurement, design, and analysis: An integrated approach. Hillsdale, NJ: Lawrence Erlbaum Associates.

Sample, J.A. (1984). Nominal group technique: An alternative to brainstorming. Journal of Extension, 22 (2). Retrieved July 8, 2064, from: http:/'/'www.joe.org/ foe 1984 march/ iw2. html. 
Setyobroto, S. 1989. Psikologi olahraga. Jakarta: Anem Kosong Anem.

Sroufe, L. Alan, Cooper, Robert G., and Ganie B. DeHart. Child developinent, Its nature and course. New York: McGraw. Hill

Smith, R.E. \& Sarason, I.G. 1993. Psychology thefrontiers of behavior. New York: Harper \& Row Publisher.

Smith, R. E., Smoll, F. L, \& Schutz. R. W. 1990. Measurement and correlates ofsport specific cognitive and somatic trait anxiety: The sport anxiety scale. Anxiety Research, 2, 263280.

Spielberger, C.S. 1972. Theory and research on anxiety: Anxiety behaviour. Academic press.

Stodolsky, S. 1985. Telling math: Origin of math aversion and anxiety. Educational Psybologist, 3, 125-133. 